\title{
A Tail Withdrawal Procedure for Assessing Analgesic Activity in Rhesus Monkeys
}

\author{
Linda A. Dykstra and James $\mathrm{H}$. Woods
}

Rhesus monkeys were restrained in chairs from which their tails hung free so that their tails could be immersed into a thermos of water. Monkeys consistently kept their tails in $38-40^{\circ} \mathrm{C}$ water for at least $20 \mathrm{sec}$, but withdrew them from $55^{\circ} \mathrm{C}$ water in 1-4 sec. Tail withdrawal latencies from $55^{\circ} \mathrm{C}$ water remained consistent over a period of $3 \mathrm{hr}$. Morphine produced dose-dependent increases in tail withdrawal latencies from $55^{\circ} \mathrm{C}$ water, whereas pentobarbital, haloperidol, and phencyclidine did not increase tail withdrawal latencies except at doses that produced marked sedation.

Key Words: Tail withdrawal; Analgesia; Morphine; 'Rhesus monkeys

\section{INTRODUCTION}

The tail withdrawal procedure that was originally developed by Janssen et al. (1963) has been used extensively to examine the effects of morphine-like compounds in rats. A number of studies (Van Bever et al., 1976; Sewell and Spencer, 1976; Tyers, 1980; Upton et al., 1982) have shown that morphine-like compounds produce dosedependent increases in the time it takes rats to withdraw their tails from $55^{\circ} \mathrm{C}$ water. Similar increases in tail withdrawal latencies have been reported following morphine administration in squirrel monkeys (Genovese and Dykstra, 1985).

In most rodent tail withdrawal procedures, withdrawal latencies are only determined once or twice in each rat, thereby limiting the contribution of conditioning factors to the withdrawal response. Since it is not practical to use large numbers of monkeys in a procedure such as this, additional training is necessary to assure that the monkeys' tail withdrawal response is dependent on the temperature of the water. It is also important to determine if the tail withdrawal response can be measured repeatedly in the same monkey, both within and between experimental sessions.

\section{METHODS}

\section{Animals}

Eight male or female rhesus monkeys (Macaca mulatta) weighing between 4.1 and $7.6 \mathrm{~kg}$ were used. All monkeys had been previously adapted to restraint chairs.

From the Department of Pharmacology, University of Michigan Medical School, Ann Arbor, Michigan. Address reprint requests to: Linda A. Dykstra, Department of Psychology, Davie Hall 013A, University of North Carolina, Chapel Hill, NC 27514.

Received June 11, 1985; revised and accepted July 18, 1985. 


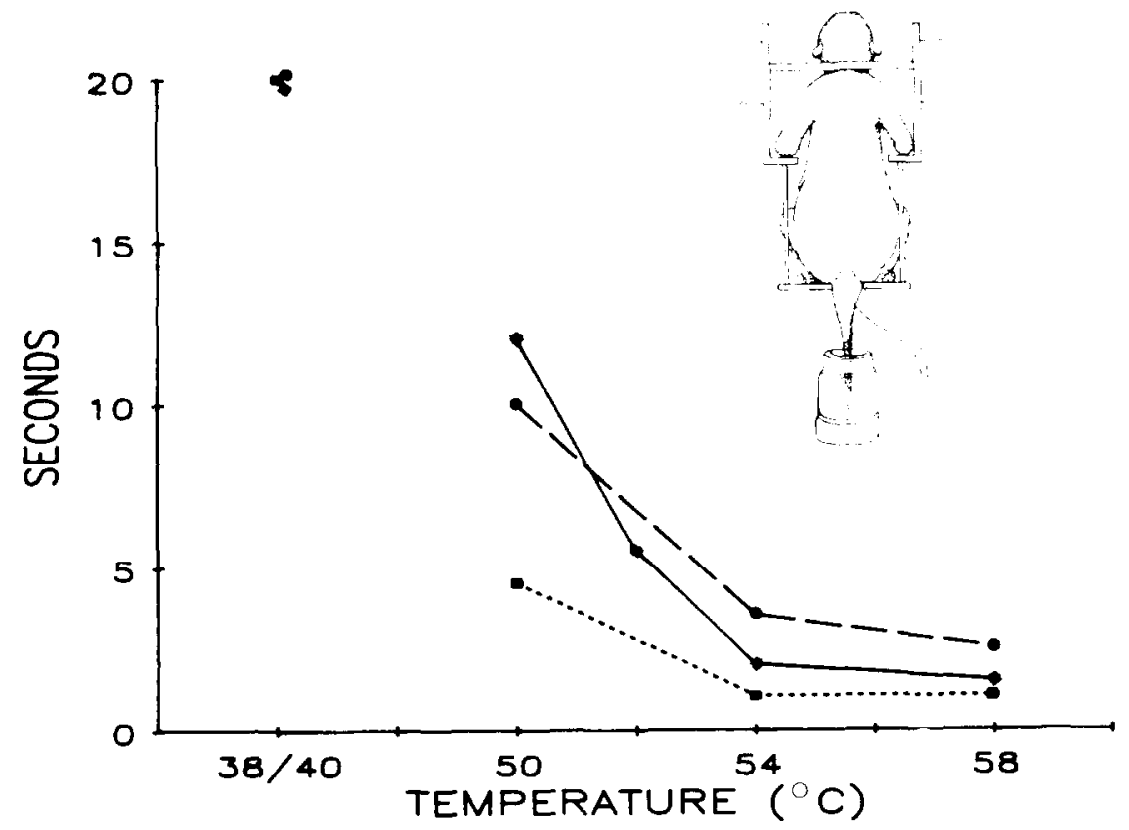

FIGURE 1. Tail withdrawal latencies in seconds as a function of waler temperature in three individual monkeys. Inset shows a rhesus monkey in the restraint chair with his tail either immersed in a thermos of water or withdrawn from the water.

Monkeys' tails were shaved, as needed, to keep them free of hair. Monkeys were allowed free access to food and water in their home cages. In addition, their diet was supplemented with fresh fruit.

\section{Apparatus}

Five primate restraint chairs were used. These loosely restrained the monkeys at the neck and positioned them in a seated position from which their tails hung free, as shown in Figure 1. The monkeys' arms were also restrained. The restraint chairs were lined up against a wall, with the monkeys' backs and tails facing away from the wall. Adjacent to the restraint chairs was a controlled-temperature water bath. A wide-mouth, one-pint thermos was used to carry water from the water bath to the monkeys, and a digital tiimer was used to measure the reaction time.

\section{Procedure}

Monkeys were first placed into restraint chairs where they remained throughout the 3-hr experimental session. Daily experimental sessions were divided into several trials spaced $30 \mathrm{~min}$ apart. On the first trial of each experimental session, the lower $10-12 \mathrm{~cm}$ of each monkey's tail was immersed into a thermos of tap water $\left(38-42^{\circ} \mathrm{C}\right)$. Only monkeys that kept their tails in tap water for at least $20 \mathrm{sec}$ continued with the experimental protocol. On subsequent trials, the monkeys' tails were immersed 
into water obtained from a water bath maintained at $55^{\circ} \mathrm{C}$. Tail withdrawal latencies were determined on each trial. If a monkey did not remove his tail from the water within $20 \mathrm{sec}$, the tail was removed by the experimenter and the latency was assigned a value of $20 \mathrm{sec}(20 \mathrm{sec}$ cutoff time). Throughout the experiment, control probes with tap water were randomly interspersed between trials with $55^{\circ} \mathrm{C}$ water. If a monkey did not keep his tail in tap water for $20 \mathrm{sec}$ during these probes, he was eliminated from the experiment for that day. Experimental sessions were run approximately twice a week, between 9 and 12 a.m. On days that experimental sessions were not run, monkeys were placed in the restraint chairs for at lcast $3 \mathrm{hr}$, and control probes with tap water were routinely administered. Of the eight monkeys used, two were only used in the initial control experiments and the remaining six were used for dose-effect determinations with each drug examined in at least four monkeys.

\section{Dose-Effect Determinations}

Dose-effect curves were obtained by administering cumulative doses of morphine $(0.3-10.0 \mathrm{mg} / \mathrm{kg})$, pentobarbital $(3.0-30 \mathrm{mg} / \mathrm{kg})$, haloperidol $(0.03-0.56 \mathrm{mg} /$ $\mathrm{kg}$ ), or phencyclidine $(0.1-1.0 \mathrm{mg} / \mathrm{kg})$. In the cumulative dosing procedure, monkeys received a drug injection after each trial (i.e., once every $30 \mathrm{~min}$ ). The amount of drug administered after each trial increased the cumulative dose by either $1 / 4$ or $1 / 2 \log$ unit. In this way an entire dose-effect curve was generated for each drug in one day. All injections were subcutaneous in the back and delivered in a volume of $0.1 \mathrm{ml} / \mathrm{kg}$.

\section{RESULTS}

\section{Control Performance}

In order to determine if tail withdrawal latencies were temperature dependent, monkeys' tails were immersed into water maintained at different temperatures, and tail withdrawal latencies were determined. Figure 1 shows temperature-effect curves obtained from three different monkeys. It can be seen that the tail withdrawal latencies from $38-40^{\circ} \mathrm{C}$ water were at least $20 \mathrm{sec}$; withdrawal latencies decreased as the temperature of the water increased.

In order to determine if tail withdrawal latencies were consistent over time, monkeys' tails were immersed in $55^{\circ} \mathrm{C}$ water once every 30 min over a period of $3 \mathrm{hr}$. Figure 2 shows time-effect curves obtained for three monkeys. Tail withdrawal latencies did not change as a function of time.

\section{Effects of Morphine}

Figure 3 shows the effects of increasing doses of morphine on tail withdrawal latencies from $55^{\circ} \mathrm{C}$ water. Mean control latencies in $55^{\circ} \mathrm{C}$ water were $2.3( \pm 0.21)$ sec. Morphine produced dose-dependent increases in tail withdrawal latencies. After tail withdrawal latencies were determined at the highest dose of morphine, $1.0 \mathrm{mg} / \mathrm{kg}$ of naloxone was administered. Thirty minutes after naloxone, tail withdrawal latencies were redetermined and found to be at control levels. 


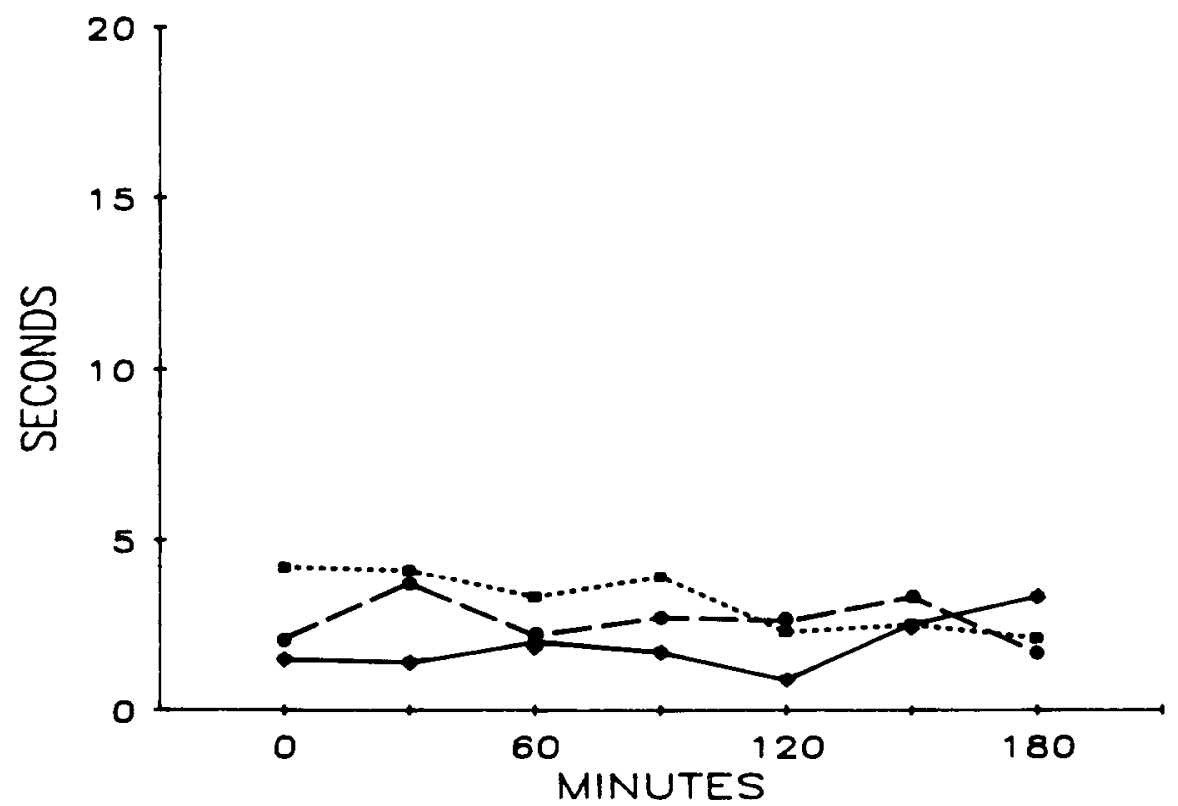

FIGURE 2. Tail withdrawal latencies in seconds from $55^{\circ} \mathrm{C}$ water as a function of time within a 3-hr experimental session. Data are shown for three individual monkeys.

\section{Effects of Phencyclidine, Pentobarbital, and Haloperidol}

Pentobarbital $(3.0-30 \mathrm{mg} / \mathrm{kg})$ and haloperidol $(0.03-0.56 \mathrm{mg} / \mathrm{kg})$ generally did not increase tail withdrawal latencies. At the highest dose of pentobarbital $(30 \mathrm{mg} / \mathrm{kg})$, all monkeys appeared to be asleep; however, they awoke when their tails were immersed in water and withdrew them within $2-4$ sec. Similarly, low doses of phencyclidine (0.1-0.3 $\mathrm{mg} / \mathrm{kg}$ ) did not increase tail withdrawal latencies; however, at 1.0 $\mathrm{mg} / \mathrm{kg}$ of phencyclidine, tail withdrawal latencies exceeded the cutoff point of 20 sec, and the monkeys showed signs of marked sedation.

TABLE 1. Tail Withdrawal Latencies from 55, 58, 60, or $62^{\circ} \mathrm{C}$ Water following $10 \mathrm{mg} / \mathrm{kg}$ of Morphine (MOR) or $1.0 \mathrm{mg} / \mathrm{kg}$ of Phencyclidine (PCP)

\begin{tabular}{ccc}
\hline \multirow{2}{*}{$\begin{array}{c}\text { Temperature } \\
\left({ }^{\circ} \mathrm{C}\right)\end{array}$} & \multicolumn{2}{c}{ Tall Withorawal LatenCY (SEC) } \\
\cline { 2 - 3 } & $10 \mathrm{MG} / \mathrm{KG} \mathrm{MOR}$ & $1.0 \mathrm{MG} / \mathrm{KG}$ PCP \\
\hline 5.5 & $>20$ & $>20$ \\
58 & $14.0(4.21)^{a}$ & $>20$ \\
60 & $8.1(4.74)$ & $>20$ \\
62 & $6.3(3.61)$ & $>20$ \\
\hline
\end{tabular}

${ }^{a}$ Standard deviations are shown in parentheses; $n=4$. 


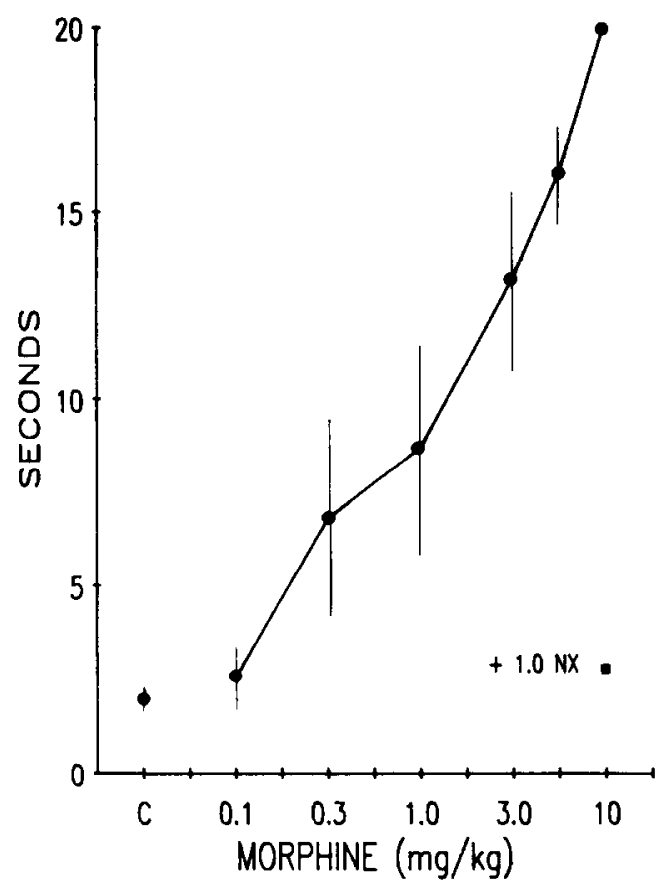

FIGURE 3. Tail withdrawal latencies in seconds from $55^{\circ} \mathrm{C}$ water following administration of increasing doses of morphine $(\mathrm{mg} / \mathrm{kg}$ ), administered cumulatively. The point at $\mathrm{C}$ represents the mean latency obtained prior to drug administration. Each point is the mean of one observation in at least four monkeys. Brackets indicate one standard error. The point at $1.0 \mathrm{Nx}$ shows the effect of $10 \mathrm{mg} / \mathrm{kg}$ morphine in combination with $1.0 \mathrm{mg} / \mathrm{kg}$ naloxone.

\section{Effects of Morphine and Phencyclidine at Different Temperatures}

Table 1 shows the effects of $10 \mathrm{mg} / \mathrm{kg}$ of morphine and $1.0 \mathrm{mg} / \mathrm{kg}$ of phencyclidine on tail withdrawal latencies from water maintained at $55,58,60$, and $62^{\circ} \mathrm{C}$. In this part of the study, trials were $10 \mathrm{~min}$ rather than $30 \mathrm{~min}$ apart. The $10-\mathrm{mg} / \mathrm{kg}$ dose of morphine increased tail withdrawal latencies from $55^{\circ} \mathrm{C}$ water to $20 \mathrm{sec}$ or more; however, this effect was reduced as the water temperature was increased. In contrast, the effects of $1.0 \mathrm{mg} / \mathrm{kg}$ phencyclidine were not attenuated at higher water temperatures.

\section{DISCUSSION}

The present report shows that the tail withdrawal procedure can be adapted for use with rhesus monkeys and that the same monkey can be used repeatedly within and between experimental sessions. This procedure requires very little training except for intermittent control probes with tap water to ensure that the tail with- 
drawal response is under control of the water temperature. Therefore, the tail withdrawal procedure provides a measure of analgesia that can be coordinated with other behavioral observations in the same monkey or used to monitor the development of drug-induced changes in analgesia that might occur as the result of tolerance or dependence.

Tail withdrawal latencies were shown to be temperature dependent and to remain consistent over periods up to $3 \mathrm{hr}$. Moreover, morphine produced dose-dependent increases in the time it took rhesus monkeys to withdraw their tails from $55^{\circ} \mathrm{C}$ water, and this effect was antagonized by naloxone. In contrast to the effects observed with morphine, neither pentobarbital nor haloperidol increased tail withdrawal latencies, and phencyclidine only increased them at doses that produced marked sedation. It is important to note that the doses of haloperidol, pentobarbital, and phencyclidine examined here were large enough to disrupt responding in other situations. For example, rates of food maintained responding in rhesus monkeys are either eliminated or markedly decreased following $0.01 \mathrm{mg} / \mathrm{kg}$ haloperidol (Woods et al., 1976), $0.32 \mathrm{mg} / \mathrm{kg}$ phencyclidine (Soloman et al., 1982), and $17.8 \mathrm{mg}$ / kg pentobarbital (Herling et al., 1979).

The effects of morphine and phencyclidine could be further differentiated by examining their effects at different water temperatures. Although $10 \mathrm{mg} / \mathrm{kg}$ of morphine increased tail withdrawal latencies from $55^{\circ} \mathrm{C}$ water to $20 \mathrm{sec}$ or more, this effect was reduced at higher temperatures. In contrast, the effects of $1.0 \mathrm{mg} / \mathrm{kg}$ of phencyclidine were not temperature dependent, suggesting that the monkey was not able to remove his tail from the water.

The data presented here are similar to those reported previously under the rat tail withdrawal procedure (Janssen et al., 1963). That is, the tail withdrawal procedure in rats is selective for morphine-like compounds with no increases in latency seen following pentobarbital, phencyclidine, and haloperidol, as well as a number of phenothiazines, anticholinergics, and psychomotor stimulants. This suggests that the tail withdrawal procedure can be used successfully to examine the analgesic effects of opioid-like compounds in monkeys.

This work was supported by U.S. Public Health Grants DA 02749 and DA 00254. L. A. Dykstra is the recipient of Research Career Development Award DA 00033.

The authors wish to express their appreciation to Mel Dickerson for expert technical assistance, Rebecca McLaughlin for assistance with the manuscript, and Debra Gmerek and Gail Winger for guidance throughout the study. The authors are also indebted to Raymond Genouese whose work with the squirrel monkey introduced them to the idea of developing this procedure for rhesus monkeys.

\section{REFERENCES}

Genovese RF, Dykstra LA (1985) Effects of morphine and $U 50,488$ (trans-3,4-dichloro-N-methyl-N-(2[1-pyrrolidinyl)cyclohexyl]-benzeneacetamide) on electric shock titration and tail withdrawal in squirrel monkeys. Fed Proc 44:1721.

Herling S, Downs DA, Woods JH (1979) Cocaine, d-amphetamine, and pentobarbital effects on re- sponding maintained by food or cocaine in rhesus monkeys. Psychopharmacology 64:261-269.

Janssen PAJ, Niemegeers CJE, Dony JGH (1963) The inhibitory effect of tentanyl and other morphinelike analgesics on the warm water induced tail withdrawal reflex in rats. Arzneimittelforsch 13:502-507. 
Sewell RDE, Spencer PSJ (1976) Antinociceptive activity of narcotic agonist and partial agonist analgesics and other agents in the tail-immersion test in mice and rats. Neuropharmacology 15:683-688.

Soloman RE, Herling S, Woods JH (1982) Discriminative stimulus effects of monohydroxylated phencyclidine metabolites in rhesus monkeys. Eur J Pharmacol 82:233-237.

Tyers MB (1980) A classification of opiate receptors that mediate antinociception in animals. $\mathrm{Br} /$ Pharmacol 69:503-512.

Upton N, Sewell RDE, Spencer PS] (1982) Differentiation of potent $\mu$ - and $\kappa$-opiate agonists using heat and pressure antinociceptive profiles and combined potency analysis. Eur I Pharmacol 78:421-429.

Van Bever WF, Niemegeers CJ, Schellakens KH, Janssen PA (1976) N-4 substituted 1-(2-arylethyl)4-piperidinyl-N-phenylpropanamides, a novel series of extremely potent analgesics with unusually high safety margins. Arzheimittelforsch 26:1548-1551.

Woods JH, Herling S, Winger G (1976) Chlorpromazine- and haloperidol-induced changes in some behavioral effects of cocaine and amphetarnine. Pruceedings of the 10th Congress of the Collegium International Neuro-Psychopharmacologicum, Quebec, 1976, pp 1485-1502. 